\title{
The Seasonal Moral Contract: The Legitimization of the Abusive Treatment of Caribbean Workers in Ontario \\ Cecilia Saez
}

Migrant seasonal farm workers have become a staple in the food production industry across rural Ontario. Under the Seasonal Agricultural Workers Program (SAWP), more than 15,000 Caribbean workers arrive in Ontario each year to address the labour shortage (Faraday, 2012). Despite the "structural necessity" of importing labour (Basok, 2002), the legal conditions that surround farm workers leave them susceptible to abuse and completely dependent on their employer (Rosemblum, 2000). Under the intersection of current Federal and Provincial laws, these programs are "entrenching and normalizing a low-wage, low-rights 'guest' workforce on terms that are incompatible with Canada's fundamental Charter of rights and freedoms, human rights, and labour rights" (Faraday, 2012, p.5).

Throughout this paper I will argue that the institutional construction of Caribbean workers as temporal and non-Canadian labour, has allowed abusive working conditions to be legitimized and normalized. Some of the historical and social factors that underlie the differences in the treatment of Canadian workers versus Caribbean workers in Canada will be explored. Furthermore, this paper will emphasize how the mistreatment of migrant workers is embedded within Canada's laws, which leads to an understanding of immigrants as "cheap, flexible labour" (Basok, 2002; Sharma, 2001). Underlying the "cheap" labour principle, this paper will also critique the "liberal and state-centered view of morality" applied to Caribbean workers (Bagchi, 2008, p. 200). Following this argument, this paper will emphasize how the creation of a new category of "non-Canadians" allows employers to strip migrant workers of most of the "human, civil and other 'rights' of citizenship available to 'Canadians'" (Sharma, 2001, p. 419).

Historically, Canada's legislation has advanced to become a pillar of moral justice; the inclusion of the Canadian Charter of Rights and Freedoms in the Constitution indicated the commitment to the protection of human rights, freedom and equity. Despite the legal advances to protect human rights, many of the regulations have 
drawn a clear distinction on who is under the protection of the Charter of Rights and who isn't. This binary code of rights reflects how "moral order 'is an organized system of rights, obligations and duties in a society, together with the criteria by which people and their activities are valued" (Harre, 1983; as quoted by Krebs and Denton, 2005. p. 633).

Reliance on "temporary" workers has increased tri-fold in the last two decades (Faraday, 2012); and this reliance on foreign workers has allowed the Canadian state to "cheapen the labour" in order to stay 'globally competitive' (Sharma, 2001, p. 419). The differential treatment of Caribbean seasonal workers is emphasized through legislative reforms that maintain "racist and nationalist" (Sharma, 2001, p. 419) discourses that perpetuate the status quo of "foreigners" being unprotected from Canadian law. Under international agreements, Caribbean seasonal workers are hired to work for up to eight months each year in Ontario to meet planting and harvesting needs (Brem, 2006). Unlike skilled-worker immigration programs, seasonal workers are denied the possibility of applying for Canadian permanent residency (Faraday, 2012).

The Seasonal Agricultural Worker Program was drafted to legally import foreign workers into Canada to meet the "temporary" seasonal needs of agricultural producers during peak harvesting and planting periods, when there are traditionally shortages of qualified Canadian workers (Rosenblum, 2009). Despite the "temporal need" of foreign labour, statistics show that between $70 \%$ and $80 \%$ of Caribbean workers come back to Canada year after year to work with the same employer (Faraday, 2012). A survey revealed that six hundred seasonal workers participate in the SAWP for seven to nine years, while nearly a quarter participate on the program for more than 10 years; some keep returning for more than 25 years (Faraday, 2012).

By law however, seasonal workers regardless of "their longterm attachment to the Canadian labour market, [...] do not acquire any rights to apply for permanent residence" (Faraday, 2012, p.15). The inability of Caribbean labourers to become Canadian residents leaves workers under the 'temporary' category, permanently (Basok, 2012). Social movements have challenged the notion, advocating that if they are "good enough to work here, they are good enough to stay" (Faraday, 2012). However, low-skill workers' characteristics seem to 
evoke strong negative moral judgments based on the perceived threat that foreigners take jobs away from Canadians (Sharma, 2001).

According the SAWP programme, only those who have worked in agriculture and are responsible for the economic wellbeing of their households, while having experienced difficulties in finding other viable sources of subsistence within their country qualify as an Ontario seasonal worker (Basok, 2002; Brem, 2006). These criteria indicate that the workers selected for the program are skilled to work in food production in Canada for most of the year, but do not have the prerequisites necessary to apply under an immigrant program that would allow them and their families, to apply for Canadian residency. Under any other immigration category, individuals have the possibility to apply for residency after two or more years of Canadian employment. Additionally, under most categories, immigrants enjoy the protection of the laws served to ensure job security, health and safety regulations of Canadian citizens from the moment they arrive into Canada (Faraday, 2012).

The reality of Caribbean workers is much different under the rules governing the Seasonal Worker Program. While in Canada, migrants work seven days a week, averaging ten hours a day to a staggering 15 hours during harvesting season; workers are not entitled to vacation pay and are not eligible to overtime pay regardless of the hours worked (Brem, 2006). Workers earn slightly above the Ontario minimum wage, a quarter of their salary is taken by income tax, C.P.P., E.I. and other costs associated with their transportation (Brem, 2006; Faraday, 2012). Despite their contribution to Canadian taxes and other work related programs, the money discounted from their pay cheques is not reflected in the benefits they receive (Basok, 2002). Furthermore, due to the widespread lack of information available to seasonal workers, most workers are not aware of their rights and do not claim the benefits accessible to them (Brem, 2006).

Work insecurity is a prevailing issue affecting migrant workers. Under the program, farm owners can send workers back to their countries indiscriminately; getting sick or challenging the bosses are seen as acceptable reasons to fire workers. If employment is terminated and the employee was not requested by name, the worker is responsible for covering relocation costs (Basok, 2002; Brem, 2006; Faraday, 2012). Critics of the legislation guiding 
migrant worker employment, argue that the program provides little protection to the employee and assigns a great deal of authority to the employer, leaving the worker in a state of work insecurity and uncertainty (Brem, 2006; Faraday, 2012). The rules that apply to foreign labour are in opposition to the laws erected to protect Canadian workers from exploitation and from physical and emotional distress.

By identifying seasonal workers as "non-Canadians", who would otherwise endure dire working conditions in the Caribbean, their exploitation in Canada is perceived as "a lesser evil" and thus, normalized and accepted. The institutionalization of regulatory measures that uphold differential treatment towards low-skilled workers in an effort to meet Canadian labour market's demands is not a novel notion. Between 1881 and1885, large numbers of Chinese immigrants were brought to Canada to work on the construction of the Canadian Pacific Railway (CPR). As soon as the railways were completed, the Federal Government moved to restrict Chinese immigration (ibid.). Lester (2002) argues that Canadians felt threatened by "Asiatic people in general, allowing only that they had their uses as cheap labour" (p. 204). To this day, much of the same discourses are maintained at governmental levels. In 2008, Robert Ford, at the time a councilor for an Etobicoke ward, said "[t]hose Oriental people work like dogs. They work their hearts out. They are workers non-stop. They sleep beside their machines. That's why they are successful in life. [...]. I'm telling you, the Oriental people, they are slowly taking over" (Ford, 2008). Expressions of foreign workers as individuals with an inherently higher level of resilience, that can work under conditions not acceptable for Canadians, has served to create the binary discourse of who is deserving of human rights and who is not within the Canadian work force.

Hence, the discourses that led to the creation of a new category of "non-Canadians" have been propagated at different levels of government. In a parliamentary debate on migrant workers applying for jobs that students and unemployed Canadians could enjoy, MP H.W. Danforth claimed:

We need this labour...and these people are used to working in the heat. They are used to working in agriculture, and they are satisfied with the pay scale... Canadians do not want to work this job-many of them do not, and have expressed this feeling in no uncertain terms-then I say that the producers of this nation are entitled to offshore competent labour from 
wherever it may come... if these people are willing to work under the conditions prevailing in Canada today and produce crops for Canadian consumers (as quoted by Sharma, 2001).

This passage reflects the fact that addressing the abusive conditions of the farming industry is not a priority; the solution is to find "other" people that would accept these conditions. Sharma (2001) argues that "parliamentary practices [...] reproduce the ideologies of racism and nationalism that help to hold in place commonsensical notions about the 'natural' superiority/inferiority of differentiated groups of people (p. 432).

Resembling the importation of migrant workers to deal with the labour shortage for the construction of the CPR, the seasonal farmers program is a "temporary" worker program that attempts to respond to the lack of readily available manual labor in the Canadian agricultural sector. Sharma (2001) argues that "much of this 'shortage' is qualitative" (p. 433) not quantitative since foreign workers are recruited for jobs Canadian citizens turn down because they are able to find employment that renders better pay, better living conditions and does not confine them to a specific employer for a set amount of time (Sharma, 2001). In her book Tomatoes and Tortillas, Basok argues that temporary workers are a "structural necessity" to the development and maintenance of the food production industry (2002, p. 12). Additionally, the author argues that the existence of the agricultural industry as we know it relies on "unfree workers", who are physically tied to their work at all times and who are unable to decline the demands of employers (Basok, 2002).

In the documentary entitled "El Contrato" (2003) ("The Contract") Min Sook Lee, follows a Mexican worker through his journey to Canada, showing the abusive reality that workers endure while employed in Ontario farms. The film shows how farm owners housed ten men in a very small apartment, leaving the workers to share one bathroom and providing them with only the bare living essentials (Lee, 2003). From the point of view of Canadian employers however, Caribbean workers are better off in Canada than in their home country, transforming the abusive living conditions experienced in Canada as "better standards of living" (anonymous, National Film board, 2003); thus, acceptable to foreign workers. 
Underlying the difference in perception for Canadian workers versus non-Canadian "temporary" workers, are the laws governing the immigrant seasonal program which differ greatly from those applied to protect "Canadian" workers. For example, under the SAWP program in Ontario, farmers have to provide workers with "acceptable" housing accommodation. However, the laws that guide the standards are bleak and very little control is exercised over the farm owners (Brem, 2006). Scholars have criticized the municipal timing of housing assessments as they happen before the workers arrive, leading to the invisibility of the conditions under which migrants actually live in (Basok, 2002; Brem, 2006).

It is the legalization of "unfreedom" that serves as the back bone of the seasonal program contract (Basok, 2002), a condition deemed illegal if applied to "Canadian" workers. Guided by economic principles of "cheap labour", the maintenance of the "non-Canadian" discourses have been necessary to craft laws that allow for the differential treatment. The research conducted for this study has not reflected a sense of moral conflict from Ontario farm owners based on migrant working conditions. On the contrary, employers understand the work opportunity they provide as "aid from the rich to the poorer states for rescuing the [...] desperately poor" (Bagchi, 2008, p. 1).

After exploring the conditions forced onto foreign workers, one must question why Caribbean workers keep coming back year after year if they endure such abusive working conditions in Canada. The answer to this question is reflected on the selection criteria of the SAWP, as well as the conditions that keep the workers from defending their rights. According to Brem (2006), the opportunity to earn Canadian wages provides Caribbean workers with a viable approach to deal with the rising unemployment and underemployment from their developing country (Brem, 2006, p. 6). The poverty experienced makes foreign workers ideal candidates to participate in the SAWP, making them the most vulnerable population within the Canadian labour market and the least resistant to abusive situations (Sharma, 2001).

If a worker is "good", then under the 'naming' practice, an employer can 'request' a specific worker to return the following harvesting season "so long as they remain satisfactory to employers" (Brem, 2006, p. 4). However, due to the institutionalization of 
abusive practices, the workers are, for the most part, unable to voice their concerns (Basok, 2002). For seasonal workers of the program, the implication of complaining or refusing to do what is asked implies being sent back or being "blacklisted" from the program (Basok, 2002; Brem, 2006). Faraday (2012), argues that this systematic deportation does not allow workers to fight their cases in court, which places employers above the judicial Canadian system. The fear of deportation prevents workers from making official complaints while in Canada (Brem, 2006).

In order to make "Canadian" wages, seasonal workers are forced to leave their families behind for extensive periods of time. Basok (2000) argues that Caribbean workers' "traditional morality" illuminates how the cultural repertoires of gender can emphasize the importance of males working to provide for their families despite abusive conditions. While working in Canada for most of the year, workers are bound by intense and inescapable proximity since workers live together and work together; the factory like settings of most greenhouses leave the workers with little to no alone time (Basok, 2001). The constant surveillance of supervisors and other workers, increases the feelings of being observed and leads to conformity to the rules.

There is no "Canadian" moral obligation towards foreign workers because nations do not act as moral entities. However, the Canadian state works at shaping people's consciousness around the boundaries of who is deserving of the laws enacted to protect workers. The organization of the category of immigrant workers normalizes the denial of rights and employment entitlements for people under the "temporal", "non-Canadian" category. The development of a binary discourse that clearly distinguishes between the rights of Canadians and non-Canadians delineates the development of a twofold code of morality.

It is this, the institutionalization of a new category of "nonCanadians" (Sharma, 2001) that legitimizes SAWP abusive regulations. According to Fiske (1992) "different types of relationships and social institutions are guided by different principles of care and justice, different sets of rights and duties, and different criteria for moral evaluation which are reflected in different kinds of moral judgments" (Krebs and Denton, 2005, p. 634). The view of Caribbean workers as "others" and the financial drive to make profits legitimizes the systematic abuse of workers. In this 
period of globalization and neo-liberalism, the laws that guide the importation of "cheap labour" allows Canada to offer a competitive market for national and international business that have seen the agricultural industry soar at the hands of Caribbean workers.

In this seasonal contract, hard work is expected from Caribbean workers for the opportunity to enjoy what is perceived as a "better" opportunity than that of their homeland employment. The lack of financial resources in their home country forces seasonal workers to abide by the rules and to return to Canada year after year. Seasonal employment allows workers to go back to home with some hard-earned money in their pockets and they do not return because they agree with the working conditions, they return because they have no choice. 


\section{Work Cited}

Basok, T. (2002). Tortillas and Tomatoes: Transmigrant Mexican harvesters in Canada. Montreal: McGill-Queen's University Press.

Brem, M. (2006) Migrant workers in Canada: a review of the Canadian Seasonal Agricultural

Workers Program. Retrieved November 26th, 2012 from www.nsi-ins.ca

Bagchi, A. K (2008) Immigrants, Morality and Neoliberalism. Institute of Social Studies. Oxford: Blackwell Publishing Ltd.

Faraday, F. (2012). Made in Canada: How the Law Constructs Migrant Workers' Insecurity. George Cedric Metcalf Charitable Foundation. Website Accessed on November 16th, 2012.

Granatstein, J.; Hilmer, L.; Mcleans N. (1999) Struggling for Justice: how Canada Tried to Bar the "Yellow Peril". Toronto

Helwig, C. \& Jasiobedzka U. (2001). The Relation between Law and Morality: Children's Reasoning about Socially Beneficial and Unjust Laws. Child Development.72(5),1382-1393. doi: 10.1111/14678624.00354

Keung, N. (2012, September 17). Abuse of migrant workers 'endemic' in Canada, new study says. The Toronto Star. Retrieved from http://www.torontostar.com

Krebs, L. \& Denton, K. (2005). Towards a More Pragmatic Approach to Morality: A Critical Evaluation of Kohlberg's Model. British Columbia: Simon Frazer University

Lee, M. S. (Director). (2003). El Contrato [Documentary]. Canada: Ontario.

Lu, V. (2008, March 06). Ford rebuked for Asian comments. The Toronto Star. Retrieved from http://www.torontostar.com

Makenzie King, W. (1935). The Diaries of William Lyon Mackenzie. National Archives of Canada. Accessed November 10th, 2012. 
Merrill, L. and Miró, R. (1996). Mexico: A Country Study. Washington: GPO for the Library of Congress. Retrieved November 10th, 2012 from http://countrystudies.us/mexico/

Sharma, N. (2001) The Social Organization of Migrant Workers in Canada.

Pietropaolo, V. (2009). Harvest pilgrims : Mexican and Caribbean Migrant Farm Workers in Canada. Toronto: Between the Lines.

Vessels, G., \& Huitt, W. (2005). Moral and character development. Presented at the National Youth at Risk Conference, Savannah, GA, March 8-10. Retrieved November 19th, 2012, from http://www.edpsycinteractive.org/ 